\title{
地震時における構造被害・室内被害の分布特性 およびその評価に関する研究

\author{
ESTIMATION OF DISTRIBUTION CHARACTERISTICS OF STRUCTURAL \\ OR INDOOR EARTHQUAKE DAMAGE IN URBAN AREA
}

\author{
北原昭男*，藤原悌三** \\ Akio KITAHARA and Teizo FUJIWARA
}

\begin{abstract}
This paper presents distribution of structural damage or indoor damage of houses (including overturning of furniture, scattering in the room and so on) in the city area as to earthquake damage of the 1993 Kushiro-oki Earthquake. The estimation method which has been developed for structural or indoor damage was also adopted into the damage in Kushiro City. Structural damage occurred on the diluvial plateau and there was few damage on the alluvial soil. On the other hand, indoor damage occurred severely in some area and its distribution characteristics was very complicated. Distribution of structural and indoor damage were strongly affected by the dynamic characteristics of surface soil with the exception of the damage by soil failure. General tendency of the damage distribution was reappeared by this method, however.
\end{abstract}

\section{Ke ywords : damage distribution, structural damage, indoor damage, the 1993 Kushiro-oki Earthquake, urban area, damage estimation \\ 被害分布、構造被害、室内被害、1993 年釧路沖地震、都市域、被害推定}

1.はじめに

都市防災の観点から都市建築物群の耐震対策や都市耐 震計画を策定していくためには、構造被害などの直接被 害を対象とするだけではなく、生活困穹や経済的困窮な どの間接的な被害を考虑することが重要である。そのた めには居住空間としての機能が地震によってどの程度失 われていくかを評価していく必要がある。また、空間機 能の損失に関連する 2 次被害としては火災や負傷者の発 生、避難不可能な事態の発生などが考えられるが、これ らは室内の散乱に起因するものが多いことが明らかにさ

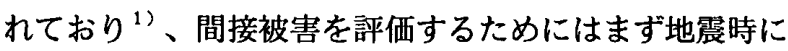
おける室内の散乱状況を正確に評価することが必要不可 欠である。

1993 年 1 月 15 日に発生した釧路沖地震では、港 湾や道路・鉄道において強い地震動による崖くずれ・地 滑り・液状化などの地盤変状に起因する被害が多数発生 した。建築構造物についても、大きな被害の大半はこの 地盤変状によるものであり、地震動の加速度レベルが高
かったにもかかわらず振動による構造的な被害は小さか った ${ }^{2)}$ 。一方、家具の転倒や室内の散乱については多く の地域で発生し、これにより多くの負傷者が発生したこ とが報告されている ${ }^{3)}$ 。しかし、このような室内におけ る被害を直接調査することは難しいため、筆者らは釧路・ 十勝支庁の建築土会の会員を対象にアンケート調查を行 い、被害の傾向を明らかにすることを試みた。

釧路沖地震による釧路市域における被害の特徴は、様 々な地質・地形を持つ比較的限定された地域において、 構造被害や室内被害などの様々な被害が発生しているこ とであろう。都市域における建築構造物群の地震被害推 定を行なうためには、被害の地域的な発生状況・分布特 性を明らかにし、入力地震動の特性、地盤条件および構 造物の条件と被害との関係を捉えていくことは不可欠で あり、このためには本地震による被害データは非常に有 益であるものと考えられる。

本研究では釧路沖地震による釧路市域における住家被 害を対象として、上記アンケート調査によって得られた

本諭文のー部は、文献 2 ) で既に発表した内容に加笵・修正を行ったものである。

* 京都大学防災研究所 助手. - 工修 Research Assoc., Disaster Prevention Research Institute, Kyoto Univ., M. Eng.

** 京都大学防災研究所 教授. 工博 Prof., Disaster Prevention Research Institute, Kyoto Univ., Dr. Eng. 
資料および釧路市などによりまとめられた被害統計資料 をもとに、構造的被害・室内被害の地域分布についてそ の特徵を明らかにした。また、筆者らはこれまでに、建 築物群の構造被害および室内における被害を物理的なモ テルに基づき、样々なレベルの被害を統一的に評価する ことを試みてきだ)-6)。ここではこの地震被害推定手 法を用いて構造的被害や室内被害を推定し、実際の被害 分布との比較により推定精度の検証を行う。また、以上 の被害分布特性に関する推定結果と実際の被害の比較を 基に、建物の構造被害・室内被害に影響をおよぼす要因 （建物の種別や耐力、表層地盤特性など）についての考 察を行った。

2. アンケート調查による構造被害・室内被害の分布

\section{1 アンケート調查の概要}

アンケート調査は京都大学防災研究所、広島大学棇合 科学部、広島工業大学工学部のメンバーからなる調査チ 一ムにより、北海道建筑士会釗路支部、同十勝支部の会 員を対象として郵送によって行われた。調査内容には、 自宅における構造的被害（建物全体・構造各部）・室内 被害 (家具の転倒・室内散乱・負傷・避難・灭災発生な ど）を初め、勤務先の建物被害、建物の補修・補強等、 ライフラインの被害とその影響、生活支障などに関する 項目が含まれている。本論文では、これらのうち釧路市 域（釧路市および釧路町）の住家における構造被害およ び室内の被害についてのみ取り上げる。なお、アンケー 卜調査の総合的な結果・考察についてはできるだけ早い 機会にまとめる予定である。

釧路支部へのアンケート配布数は 349 件で、1 60 件（回収率 $45.8 \%$ ）の回答が奇せられた。この内釧路 市域に住家があるのは 151 件であった。釧路市は一般 に図 1 中に太い実線で示した 7つの地区に分けられる。 本研究ではこれらの地区毎に結果 をまとめるが、区域の広い春採、 橋南、愛国、鳥取の各地区につい ては、地形や地質条件などの変化 をより詳細に考虑するためさらに $2 \sim 3$ 分割した。

図 2 には地区別の回答数及び、 回答のあった住家の構造種別、建 物種別、建物階数、建筑年の分布 を示す。回答のあった住家はほぼ 各地区に分散しているが、橋北地 区は業務地域であり夜間人口も少 ないため、回答数は非常に少なか った。表 1 には回答数の地区別分 布と平成 2 年度国勢調查による各
地区の世帯数の地区別割合を示す。両者を比較するとほ ほ同じ值を示しており、回答の地域的なばらつきは少な いものと考えられる。

アンケートの結果から釧路市域の住家の特徴を記すと、 建物種別では 1 戸建てが圧倒的に多く全体の $76 \%$ を占 めている。構造別では木造軸組工法によるものが多く、 $\mathrm{RC}$ 造は $10 \%$ 程度である。建物階数は 2 階建てが多い。 また、建築年は比較的新しいものが多く、特に建築基準 法の改正以後のものが約 $30 \%$ を占めている。

\section{2 構造被害の地域分布}

アンケートの結果をまとめるに先立ち、釧路市災害対 策本部より得られた資料（1993 年2月19日現在）

表 1 アンケート回答数と国势調查による世帯数の割合の比較

\begin{tabular}{|c|c|c|c|c|c|c|c|c|}
\hline 地区名 & 㟢採 & 橋南 & 梧北 & 鉄北 & 愛国 & 鳥取 & 大楽毛 & 全域 \\
\hline-5 & 31 & 28 & J & 23 & 25 & 17 & a & 133 \\
\hline 割食 & 23.3 & 21.1 & 2.3 & 17.8 & 18.8 & 12.8 & 4.5 & 100 \\
\hline 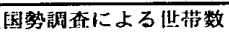 & 17190 & 146 & 3205 & 366 & 12798 & 6 & 565 & $\overline{74160}$ \\
\hline & 23.2 & 8.9 & 4.3 & 16.1 & 17.3 & 25 & & 100 \\
\hline
\end{tabular}

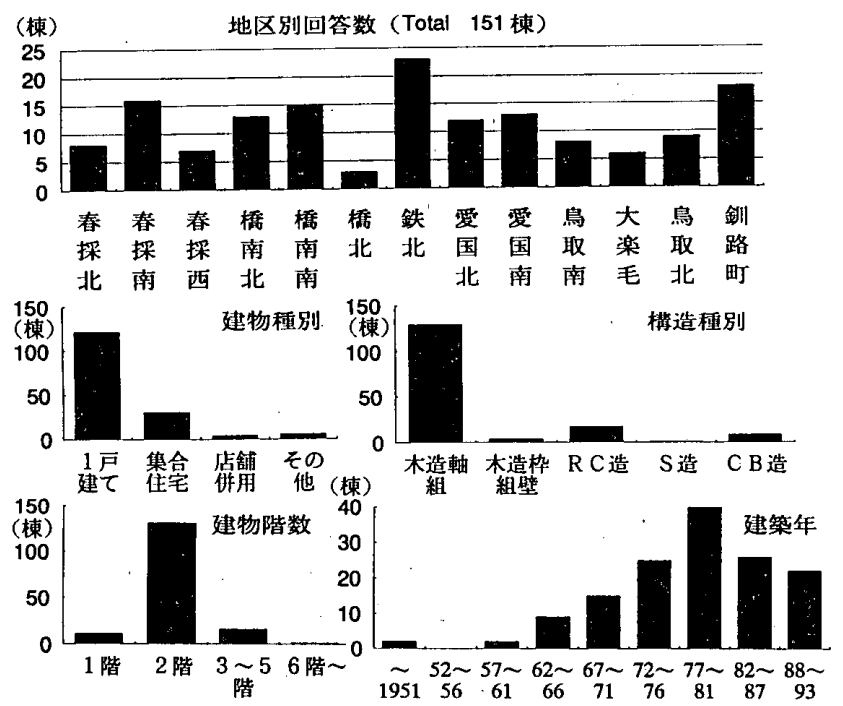

図 2 アンケートの回答における地区別、建物種別、構造種別、 建物階数別、建築年代別の割合

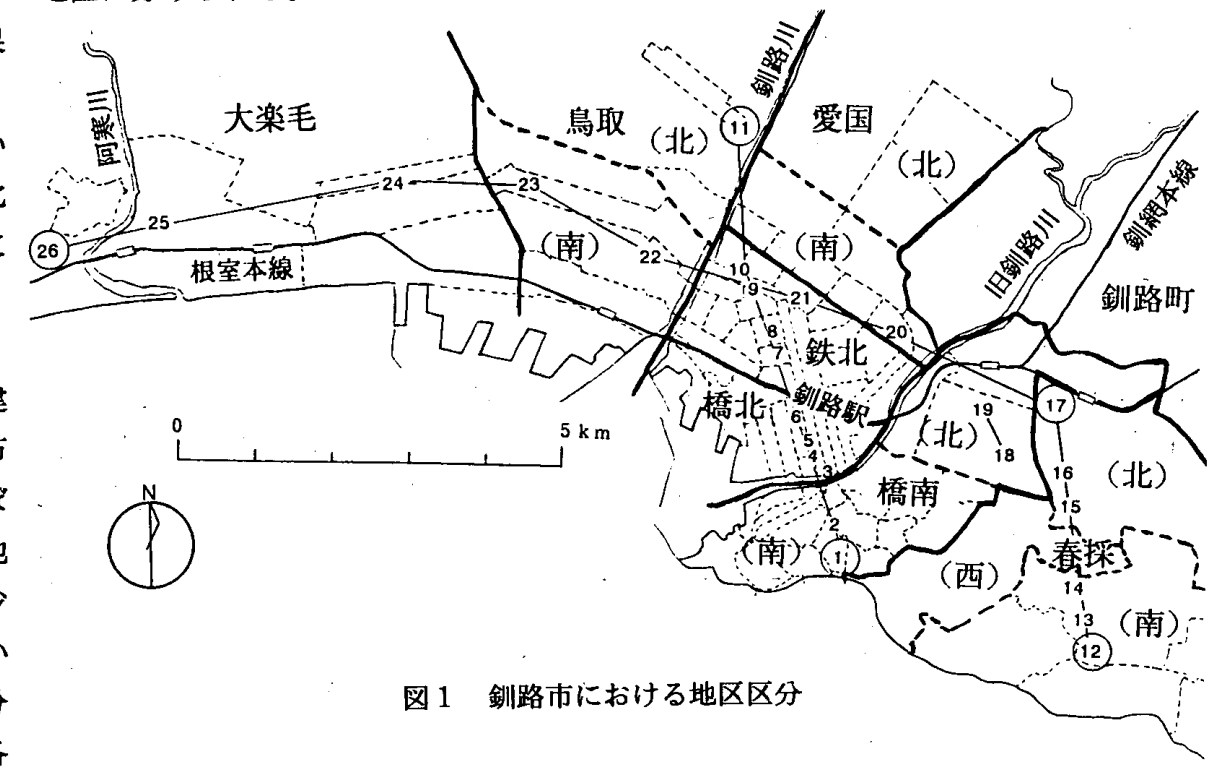


をもとに、釧路市内の各町ごと（緑ヶ岡・武佐について は各丁目ごと）に一部壊以上の被害件数を求めた。さら にこれを各町（各丁目）の推定住宅戸数で割って被害率 を求め、図 3 に示した。各町の住宅戸数は平成 2 年度の 国勢調査の結果（各町の人口、住宅種別ごとの構成比な ど）を用いて推定した。崖崩れなどによって被害が多く 発生した洪積台地上の緑ヶ岡 6 丁目で $24.3 \%$ と最も高 く、ついで同 5丁目、武佐 2丁目、材木町などで10\% 以上の値を示している。旧釧路川以東の地区は主に洪積 台地上に存在するが、若松 ${ }^{7}$ が示したとうり、被害の大 きかった上記の地域では、以前谷であった部分を埋め立 てた造成地が複雑に入り組んでいる。この様な人工改変 された地盤が地震によって破壊し、構造物の被害につな がったもの之考えられる。その他の旧釧路川以東の地区 では、橋南(南)の各町や武佐 2 丁目、貝塚など、台地の 縁端部の地点で $7 \%$ 程度の値を示しているが、春採や桜 ヶ岡などの地域では比較的小さな值となっている。

旧釧路川より西の地域では釧路川や旧釧路川などによ る沖積平地が広がっている。被害率は、釧路駅南の北大 通り周辺で $11.8 \%$ と大きな值を示しているが、その他 は比較的低い值であった。釧路川と旧釧路川の間の地域

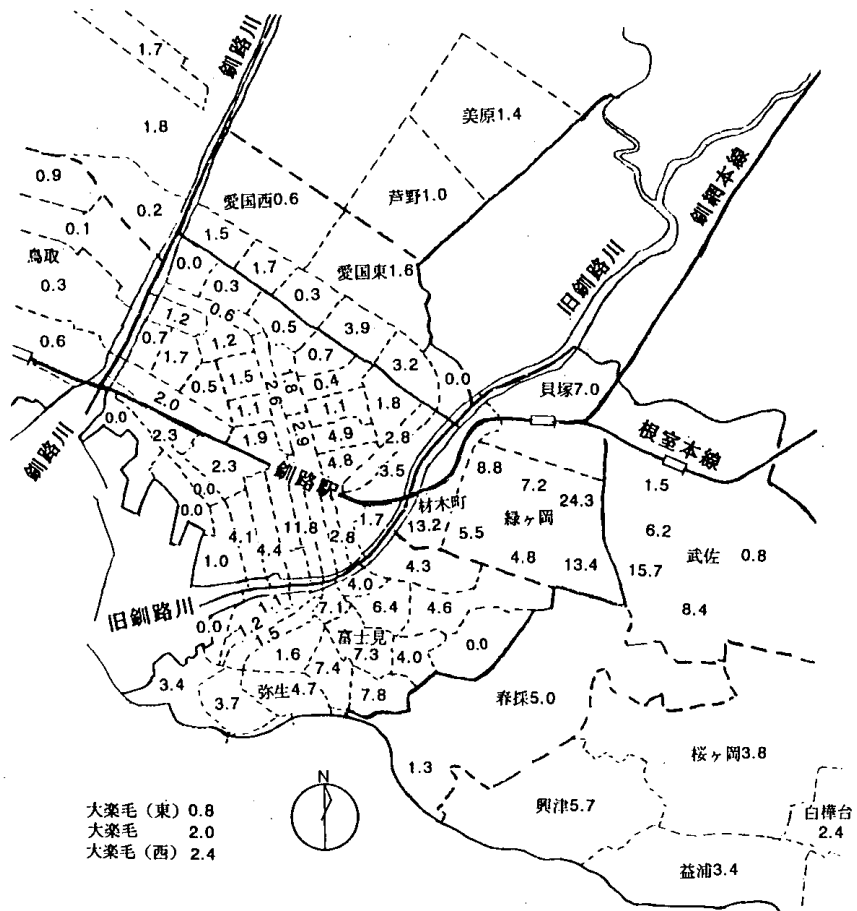

図 3 釧路市内の一部壊以上の被害率（1993年2月19日現在）

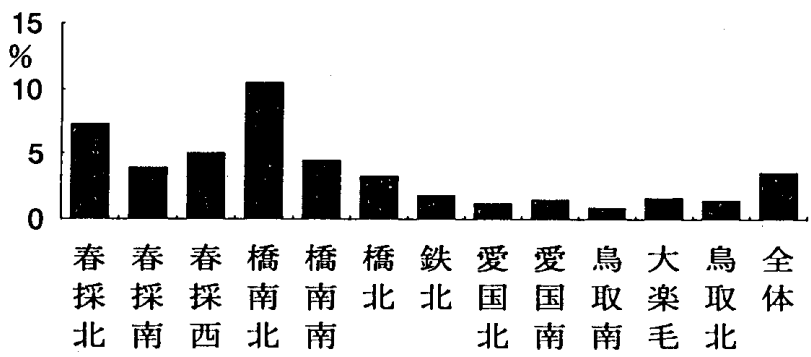

図4被害統計による地区別の被害率
では、被害率は旧釧路川に近いほど大きく、離れるにし たがって小さくなる傾向を示している。釧路市域におけ る沖積首基底の等深度図を参照する之、基底は橋北地区 で10 30 m程度、釧路川近傍では $70 \mathrm{~m}$ 程度と、基 本的には西へ行くほど深くなっており、沖積首が厚くな るほど被害率は小さくなる傾向を示している。基盤地震 動の卓越振動数が比較的高かったと考えられるため、軟 弱層が薄い（固有振動数が高い）地盤における增幅率の 方が大きくなった可能性が考えられる。また、美原・芦 野や鳥取の北などの北部地域は釧路湿原に近く地盤は相 対的に軟弱であるが、被害率は大きくはなかった。図 4 にはこれらの被害率を各地区毎に求めたものを示した。

図 5 には、アンケート調查による家屋全体の構造被害 の分布状況を示す。全壊・半壊之評価された住家はそれ ぞれ1棟のみであった。また、一部壊と評価された住家 については、各部位の被害状況を参照し、一部壊と軽微 な被害に分類した。一部壊の住家は橋南(北、南)の台地 縁端部に多く存在しており、被害統計との傾向は一致し ている。また、軽微な被害はかなり広い地域に分布して いる。図 6 には各地区毎の被害程度の割合を示す。一部 壊以上の被害に関しては、被害統計（図 4 ）之同様に橋 南地区で他地区に較へて大きな被害率を示しているが、 全般的にはやや大きめの值を示している。しかし、軽微 な被害まで含めて被害発生の分布をみると、アンケート の結果はほぼ図 4 と同様の傾向を示していることが䛃み 取れる。母数は少ないものの被害分布の傾向をほぼ表現

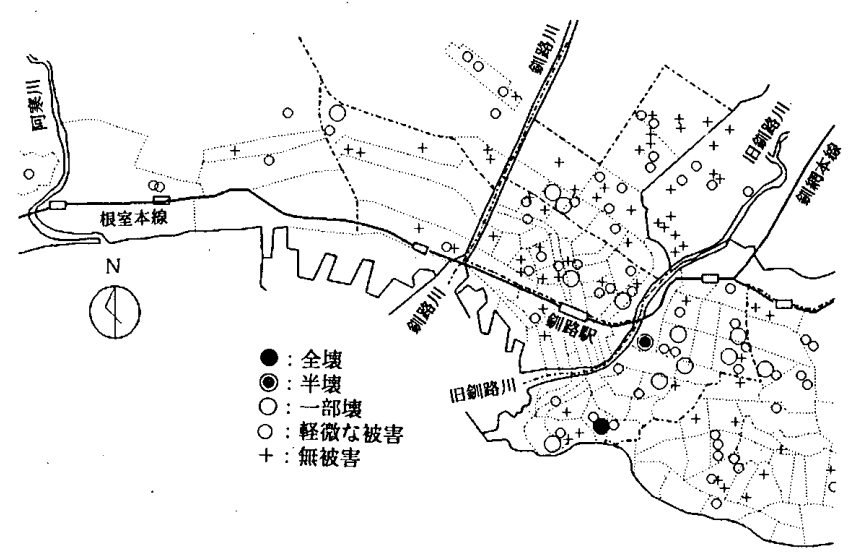

図 5 アンケート調查による構造被害の分布

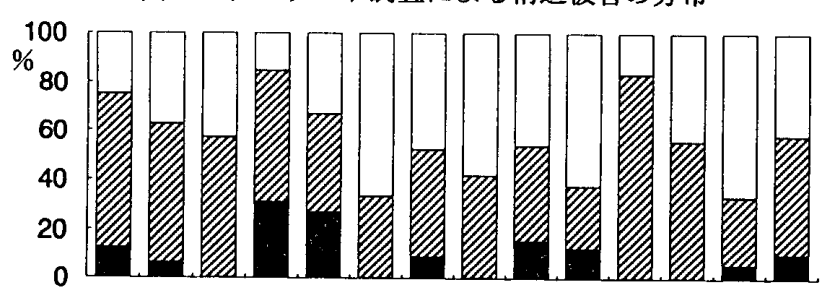

春春春橋橋橋鉄爱爱鳥大鳥釧全 採採採南南北北国国取楽取路体 北南西北南北南南毛北町

一一部壊以上 $\mathbb{Z}$ 軽微な被害 $\square$ 被害なし

図 6 アンケート調查による構造被害の地区別割合 
しており、回答数の分布と併せ考えると、本アンケート 調査の一般性は十分にあるものと考えられる。

つぎに、建物各部の被害について各地区での被害発生 の割合を図 7 に示す。なお、これらの割合は、ひび割れ 発生程度の軽微な被害も含めた被害発生率を示している。 春採(北)、橋南(北、南)などの地区では、基䃈・床の被害 が多く発生しており、地盤変状によって被害が多く発生 したことを示している。壁の被害は多くの地区で $50 \%$ 近く発生しているが、その多くは外壁のひび割れなどの 軽微なものであった。煙突の被害は橋南(北)・春採(北)で 多く発生したことが読み取れる。大楽毛地区では図 6、 図 7 共に周辺の地区と比べる、やや大きな被害を示し ている。

\section{3 室内における被害の地域分布}

室内の被害に関して、アンケートでは各家具の転倒・ 移動状況、散乱状況、負傷や火災の発生可能性、室外 の避難状況、耐震対策等についての調查を行なった。こ こでは、室内被害のうち家具の転倒・移動および室内の 散乱の地域分布についてまとめた。各家庭の家具の転倒・

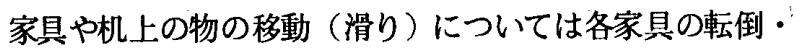
移動状況より、室内の散乱状況についてば収納物の落下 の程度、室内の散乱面積などのアンケート結果を用いて、 レベル0（被害無し）から4（重い被害）までの5段階 に評価することを試みた。各レベルの評価は表 2 に示し た被害状況を目安として行なった。

これらの結果をもとに図 8（a）には家具の転倒に関 して、（b ）には室内の散乱状況に関して、それぞれの 被害の地域分布を示した。家具の転倒に関しては、レベ ル 2 以上の大きな被害は局所的に発生しており、その多 くは湿原を埋め立てた場所や河川の縁などの地盤が軟弱 であろうと考えられる場所で発生しているように見て取 れる。また、洪積台地上の春採(西)にも被害が集中して いる。一方、橋南(北、南)や春採(北)では構造被害は大き かったが、家具は転倒しなかったケースも見られる。沖 積地の西方（鳥取・大楽毛地区）では家具の転倒はほと んど発生していない。室内の散乱については洪積台地上

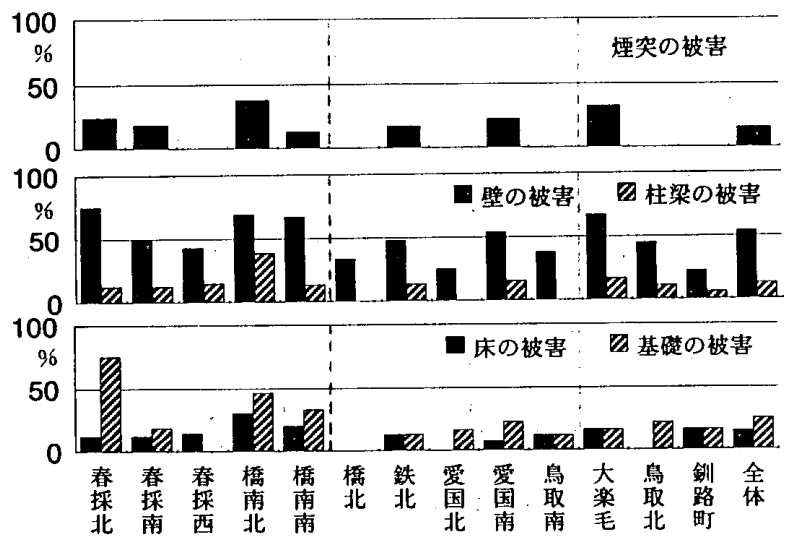

図 7 アンケート調查による構造各部の被害の地区別割合
や湿原に近い地区で多く発生している。しかし、家具の 転倒に比べると被害は全市域に広がっており、ほとんど の地域でレベル 2 程度の散乱が発生している。

家具の転倒、家具の移動、室内散乱のそれぞれの評点 を、各地区で平均して図 9 に示した。各項目のうち $1 \mathrm{~F}$ と記したものは戸建ての 1 階または集合住宅で居住階が 1 階の場合、 $2 \mathrm{~F}$ は戸建ての 2 階以上の部屋または集合 住宅で居住階が 2 階以上の場合を示している。室内の散 乱については春採(西)・橋南(北、南)で平均 2 以上の值を、 ついで春採(北)、愛国(北、南)、釧路町が大きな值を示し た。家具の移動についてもほぼ同粎の傾向を示した。し かし、散乱の大きかった地区のうち、春採(西)では家具 の転倒も 2 程度であったのに対し、春採(北)や橋南(南)で は転倒は 1 以下の小さな值であった。この様に、釧路川

表 2 家具の転倒や室内散乱のランク付けの目安

\begin{tabular}{|c|c|c|c|}
\hline 評点 & 家具の転倒 & 移動・すべり & 室内の散乱 \\
\hline 4 & $\begin{array}{l}\text { 部屋中のほぼ全ての } \\
\text { 家具が転倒 }\end{array}$ & $\begin{array}{l}\text { 部屋中のほぼ全ての } \\
\text { 家具がかなり移動 }\end{array}$ & $\begin{array}{l}\text { 部痽中が足の踏み場 } \\
\text { るないぼに散乱 }\end{array}$ \\
\hline 3 & $\begin{array}{l}\text { 幅厚の物は転椡せず } \\
\text { 本棚などはほぼ転倒 }\end{array}$ & $\begin{array}{l}\text { はぼ全ての家具が少 } \\
\text { し移動 }\end{array}$ & $\begin{array}{l}\text { 部屋の休面積の半分 } \\
\text { 以上に収納物が散乱 }\end{array}$ \\
\hline 2 & $\begin{array}{l}\text { 比較的厚みの薄い } \\
\text { 家具がいくつか転倒 }\end{array}$ & $\begin{array}{l}\text { いっっかの家具が移 } \\
\text { 動・机上の物が落下 }\end{array}$ & $\begin{array}{l}\text { 部屋の床面栍の数 } 10 \\
\% \text { に収納物が散乱 }\end{array}$ \\
\hline 1 & $\begin{array}{l}\text { 不安定な物などのい } \\
\text { くつかが転到 }\end{array}$ & $\begin{array}{l}\text { 机上の物などのいく } \\
\text { つかが滑って落下 }\end{array}$ & $\begin{array}{l}\text { 机上の物や不安定な } \\
\text { 物が落下して散乱 }\end{array}$ \\
\hline 0 & 転倒物無し & 移動した物軺し & 散乱せず \\
\hline
\end{tabular}

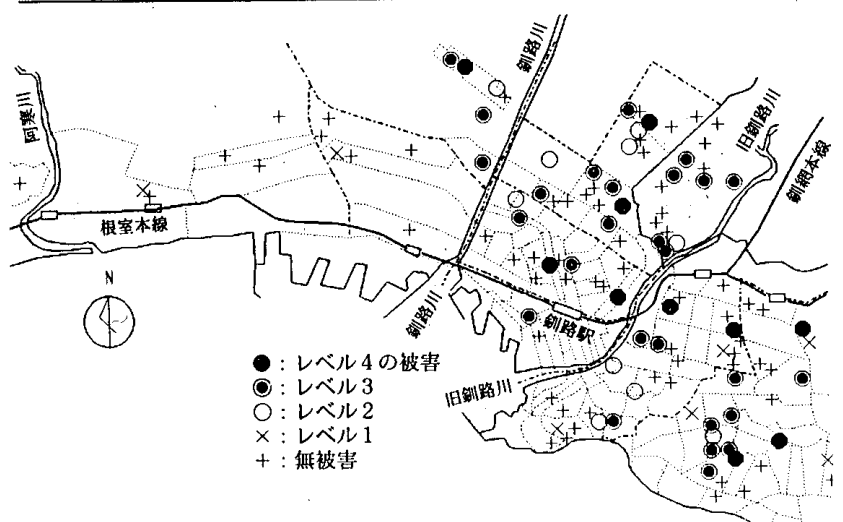

図 8（a）アンケート調査による家具の転倒被害の分布

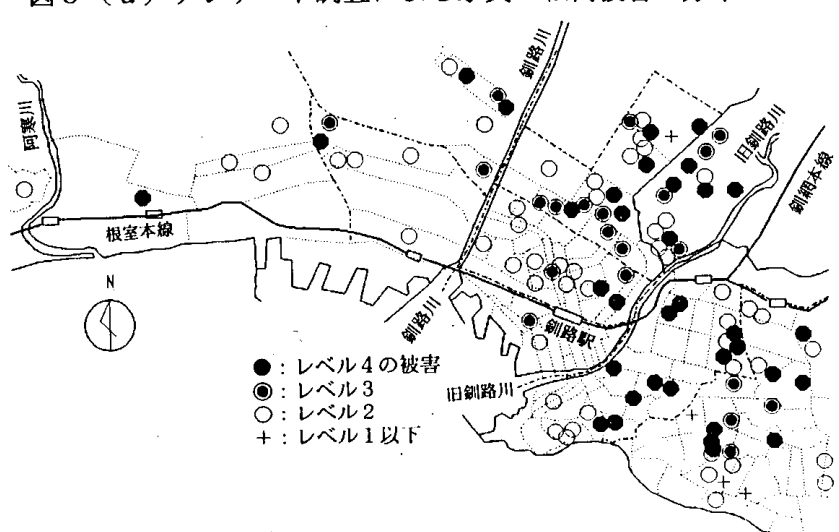

図 8 (b) アンケート調查による室内の散乱被害の分布 
以東の地区では散乱のみが卓越して発生する地域、家具 の転倒も同時に発生する地域がそれぞれ存在することが 読み取れる。1 階と 2 階以上の被害の傾向はほぼ似通っ たものとなっている。

これまでに述べてきた被害の地区別の分布特性をまと めると概略以下の通りとなる。構造被害は、橋南(北)、 春採(北)で最もひどく、ついで洪積台地上のその他の地 区の順となった。また、橋北地区でもやや大きな被害を 生じた。家具の転倒は橋南(北)や春採(西)で多く発生し、 ついで湿原近傍の鳥取(北)に多く見られた。一方、室内 の散乱は洪積台地上の各地区の程度が大きかったが、転 倒被害と比べると春採(南)では被害は小さく、逆に橋南 (南)では被害が大きかった。また、橋北の 2 階以上や愛 国地区でもやや大きな被害が発生していた。

\section{3. 住家の構造被害および室内における被害の推定}

これまでに構筑してきた地震応答推定手法 ${ }^{4) 、 5)}$ を用 いれば概略的に構造物の地震応答を求めることができ、 これらの推定量を用いて構造的な被害や室内の散乱状況

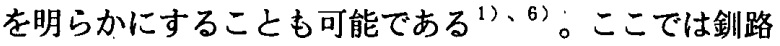
沖地震による構造被害、室内被害に影響を及ぼしている 要因を探ると共にこの手法の妥当性を検証することを目 的として、上記の推定手法を釧路沖地震の場合に適用す ることを試みた。

\section{1 解析手法}

本解析手法の概要を順をおって以下に記す。

（1）工学的基盤面での入力地震動

地盤の応答解析を行うためには、まず基盤地震動を設 定する必要がある。ここでは、釧路市域に広く存在する

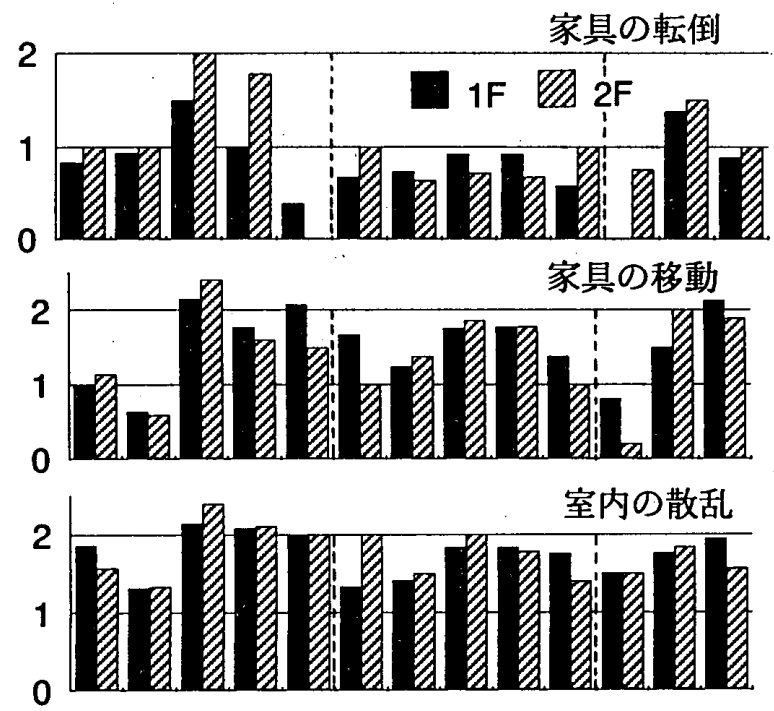

春春春橋橋橋鉄要爱鳥大鳥釧 採採採南南北北国国取楽取路 北南西北南北南南毛北町 図 9 アンケート調查による室内被害の地区別割合
安定した浦幌層群および釧路層群（N值 50 以上）を共 通基盤と考え基盤地震動を設定する。しかし、現状では 適当なディジタルデータは見あたらないので、ここでは 釧路気象台の地表における建築研究所の観測記録 ${ }^{8)}$ を参 考にして地震動を作成した。その設定手順を以下に示す。

基盤動としては開放基盤での波形として、金井・田治 見フィルターを用い、位相に一様乱数を与えて模擬地震 動を作成し、用いることとする。また、本解析で対象と する地盤および構造物の振動数は $1 \mathrm{H} \mathrm{z} \sim 4 \mathrm{H} \mathrm{z}$ 程度の 範囲にあり、この範囲で精度が得られるように基盤動を 設定する。まず、この基盤動および気象台に最も近いボ ーリングデータを用いて以下の（2）（3）に記した手 法で表層地震動を推定し、建築研究所の記録（N 153 E 成分）と比較する。両者の比較には、加速度および速 度の応答スペクトルの形状およびそれらを周期 0.1 2.0 sec.の範囲で積分した值を用い、これらが一致する ように繰り返し計算を行なってフィルターの卓越振動数、 減衰定数および基盤動の最大加速度を決定した。その結 果、それぞれ $3.9 \mathrm{~Hz} 、 0.5 、 445 \mathrm{~g}$ a 1 という值 が得られた。図 10 には応答スペクトルの比較と設定し た基盤動のフーリエ振幅スペクトルを示す。川瀬 ${ }^{9)}$ は北 海道内の気象台における $8 つ の$ 観測記録より原地動スペ クトルを求めているが、これを見ると $4 \mathrm{~Hz}$ 程度をピー クとした特性をもっており、上記の振動数に関する設定 はほぼ妥当であると考えられる。波形の包絡線について は気象台における表層動の主要部の継続時間が観測結果 と同程度になるように指数型の関数を用いて設定した。

（2）表層地盤のモデル化

北海道建築士会釧路支部のまとめたボーリングデータ 集 $^{10)}$ を参照して解析地点の表首地盤を成層地盤として せん断質点系にモデル化した。しかし、これらのボーリ ングデー夕は比較的浅い地盤までしか得られていないの で、ここでは地質断面図が得られている図 1 中の橋南 (南)から愛国地区（地点 $1 \sim 11$ ）、春採(南)から春採(北)

(地点 $12 \sim 17$ ) 、春採(北)加大楽毛（地点 $17 \sim$ 26 ) の 3 つの測線上の地点书よび橋南（北：緑ヶ岡） の2地点（1 8、19）を対象としてモデル化を行った。 ボーリングデータと基盤の間は地質断面図や数本ある深 井戸のデータを参照して推定した。各層のせん断波速度 は鏡味・後藤 ${ }^{11)}$ による推定式を用いて、各層の N 值、 層厚、地盤種別により求めた。

（3）表層地震動の推定

上で設定した基盤動と地盤モテルを用いて、弾塑性地 震応答解析を行い表層地盤における地震動を求めた。各 層の復元力特性には大崎・原ら ${ }^{12)}$ による土の非排水強 度で規準化された $\mathrm{R}$ - Oモデルを用いた。数值積分には Runge KuttaGill法を用い、時間刻み 0.01 secで 4096 ステップについて応答解析を行った。 
(4) 構造物の動的特性のモデル化 ${ }^{4) 、 5) ~}$

これまでの研究では木造住宅及びR C 造構造物の動的 特性のモデル化を行ってきた。ここでは、その内、解析 の対象として在来軸組工法による木造住宅（記号W Sで 表す）および一般的な低層 R C 構造物（記号：RＣ）を 選ひ、それぞれをせん断質点系にモデル化した。各層の 復元力特性はスケルトンカーブと履歴特性に分けて、既 往の実験結果や設計例を参照して設定した。構造物のせ ん断耐力は建物の壁量に応じてせん断耐力係数 Cy (ベ ースシアー係数に相当）を算出し、設計の基準点におい てこの係数に応じたせん断耐力を持つものとした。実際 の構造物の高さ方向のせん断耐力分布については、構造 物が旧基準法（記号：O）、新基準法（記号：N），の考 え方にそって設計されているものと仮定し、これによっ て各層の層せん断耐力を算定した。その他の諸量（各階 の重量、粘性減衰など）は設計指針や既往の実験結果な どを参照して設定した。なお、宮城県沖地震による構造 物の応答・被害を本モデルを用いて推定し、実際の被害 と比較することにより、精度の検証を行なっている。

\section{（5）構造物の応答の推定}

上で設定した表層地震動と構造物モデルを用いて（3） と同じ条件で弾塑性地震応答解析を行い、構造物各階に おける最大地震応答（加速度、速度、変位など）を求め た。なお、基盤地震動は位相情報として一様乱数を与え ているので、ここでは一様乱数を変化させて 30 個の基 盤地震動を作成し、それぞれの地震動に応じて地盤およ び構造物の地震応答解析を行い、応答量はこれら30 回 の計算結果の平均値として求めた。

(6)- 各フロアでの家具の転倒・室内散乱の推定 ${ }^{1)}$

家具のロッキング振動は、地震時におけるフロアの加 速度、速度に依存する。加速度に関しては家具の端が浮 き上がる時の重心でのモーメントの釣合より、また、速 度に関しては家具の重心が鉊直線を越えるとき（重心が 元に戻らずさらに回転してしまう場合）のエネルギーの 釣合よりそれぞれその下限值を示す尺度が求められ、振 動台実験などによっても検証・修正されている ${ }^{31} 。 こ$ こでは、家具の転倒率をこの尺度を下限（平均 $-3 \times$ 標
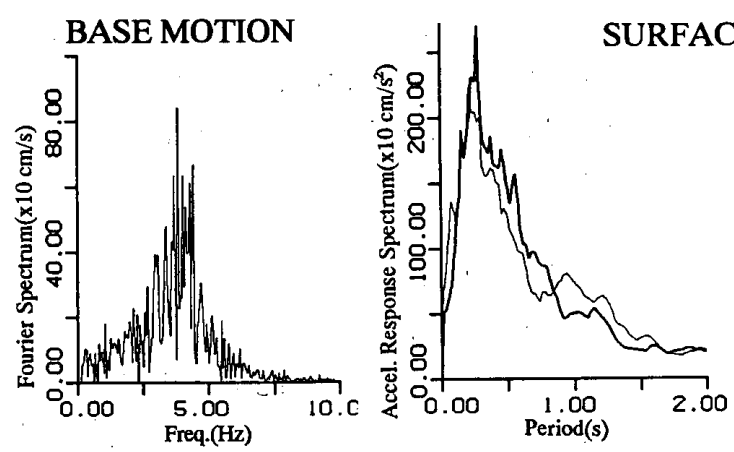

SURFACE MOTION

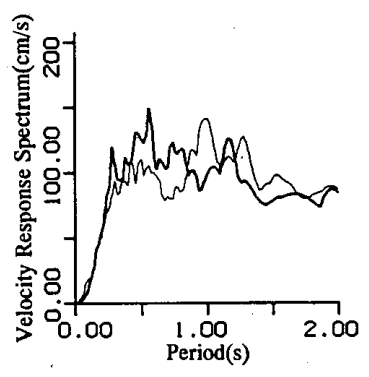

図 100 設定基盤動のフーリエスペクトルおよび釧路気象台における推定 地震動（太線）上観測地震動（細線）の加速度・速度応答スペクトルの比較
準偏差）とする正規分布で仮定し、震度階の表現にも合 致するように平均値を設定し、家具の転倒率とフロアの 最大加速度・最大速度との関係を求める。また、加速度 に関する下限値は家具の端が浮き上がり始める状態、す なわち家具がロッキングをし始めそれに伴い収納物が落 下を始める状態を示すものと考えられる。そこで、ここ では加速度の尺度を用いた正規分布を収納物の落下率と フロアの最大加速度との関係にも用いることとした。こ れらの関係式により、フロアの最大加速度・速度が求ま れば、家具の転倒率、収納物の落下率が求められる。

室内の散乱面積は上で求めた家具の転倒率に、転倒に よって占められる面積を掛け合わせたものと、収納物の 落下率に、落下物の散乱する面積を掛け合わせたものの 集合和で得られる。ここでは、得られた散乱面積を室内 の可住面積（部屋面積から家具などによって占められる 面積を差し引いたもの）で割ることによって散乱率を定 義している。

\section{2 表層地盤・表層地震動の特性}

表層地盤の周波数特性を調へるために、3.1の（2） で作成したモデルを用いて各地点の伝達関数を求めて図 11 に示した。なお、Q值はすへてての層で 20 と仮定し た。各図中の数字の内、最上段は地点番号を示し、その 下の数值は 1 次、2 次のピークの振動数をそれぞれ示し ている。また、これ以降、地区名・地名のあとの括弧内 の数字は図 1 中の地点番号を示している。1から11の 測線では、橋南(南) $(1,2)$ ではピークは $2 \mathrm{~Hz}$ 程度で あるのに対し橋北 $(3 、 4)$ の南部では $2.5 \sim 3 \mathrm{H} \mathrm{z}$ と 高くなっている。鉄北地区以北 $(7 \sim 11)$ では 1 〜

$1.5 \mathrm{~Hz}$ 程度の低い值を示した。松岡・翠川による常時 微動観測の結果 ${ }^{14)}$ では、橋南(南)で $3 \mathrm{H} \mathrm{z}$ 以上、橋北で $1.2 \sim 2.0 \mathrm{~Hz}$ 、鉄北以北で $1.2 \mathrm{~Hz}$ 以下となってお り、本モデルは橋南地区でやや低く、橋北南部でやや高 い評価となっている以外は観測結果と良い一致を示して いる。地点 12 から 19 では春採(南) (12〜14) で $3 \mathrm{~Hz}$ 以上の高い数值を示している。地点 20 から 26 にかけては湿原に近い地点でもあり、1 1.5 H z 付 近に第一のピークがある。微動観測結果では、春採南で $2.2 \sim 4.0 \mathrm{~Hz}$ 、湿原近傍で $1.2 \sim$ $1.8 \mathrm{H} \mathrm{z}$ 程度と、これらも良く一致し ている。

つぎに、3.1の（ 3 ）で求めた表層 地震動の最大加速度および最大速度を 図 12 に示す。図の横軸は各地点の相 対的な距離を示している。釧路気象台 近傍（記号：K）では表層動の加速度 および速度の応答スペクトルの面積が 観測值と等しくなるように基盤動を設 定したにもかかわらず、最大加速度は 
$517 \mathrm{~g} \mathrm{a} 1$ となり、错測値（637 g a 1) よりは小 さな値となった。この原因としては、観測波には高い振 動数に小さなピークがあること、表首動の推定手法には 誤差が含まれていることなどが考えられる。相対的には、 春採(南)の各町（12１4） 户武佐2丁目（１６）、 緑ヶ岡 5 丁目（18）で最大加速度は $500 \mathrm{~g}$ a 1 を越 える大きな值を示し、北部・西部の沖積地盤上の地域 $(7 \sim 11 、 21 \sim 26)$ では $300 \sim 350 \mathrm{~g}$ a 1 程 度であった。詳しい設置場所や設置条件が不明なため詳 細な比較はできないが 西部の大楽毛橋（地点 25 付近）

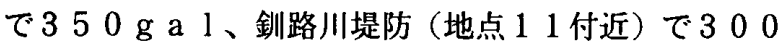
〜320 g a 1 という最大加速度が観測されており、推 定結果はこれらの值について良い一致を示している。

最大速度は各地点で比較的大きな值を示し、釧路駅

（6）付近で 60 kineと最も大きくなった。一方、鉄北 地区や武佐、緑ヶ岡などでは 40 kine 程度の值を示した。

\section{3 構造被害・室内被害の分布}

3.1 で示した手法により、在来軸組工法による 2 階建 ての木造住宅（記号W S - N-2：新基準によるもの、 W S $-\mathrm{O}-2$ ：旧基準によるもの）および新旧基準によ る $\mathrm{R} \mathrm{C}$ 造 2 階建て $(\mathrm{R} \mathrm{C}-\mathrm{N}-2 、 \mathrm{RC}-\mathrm{O}-2)$ 、新 旧基準による 5 階建て（ $\mathrm{R} \mathrm{C}-\mathrm{N}-5 、 \mathrm{R} \mathrm{C}-\mathrm{O}-5$ ） の建物について、各階のフロアの最大応答加速度 ・ 層間 変位（ $\mathrm{RC}$ 造については首間変形角）を求めた。また、 これらの応答量をもとに室内の散乱率を算出した。構造 物のせん断耐力係数 $C y$ （ベースシアー係数に相当）に 関しては、 R C 造については壁量調查の結果を参照して 平均的な值として 1.0 を用いた。また、木造住宅につい ては $C y$ はパラメータとして考え、設計の基準值に相当 する 0.2 とその倍の 0.4 を用い、記号末尾の括弧内の 数字で表した。基準法改正以後の構造物を対象として、 本州の数都市において行なわれた壁量調查の結果をまと めると、Cyの最頻値は 0.2 を越えたところにある4)。
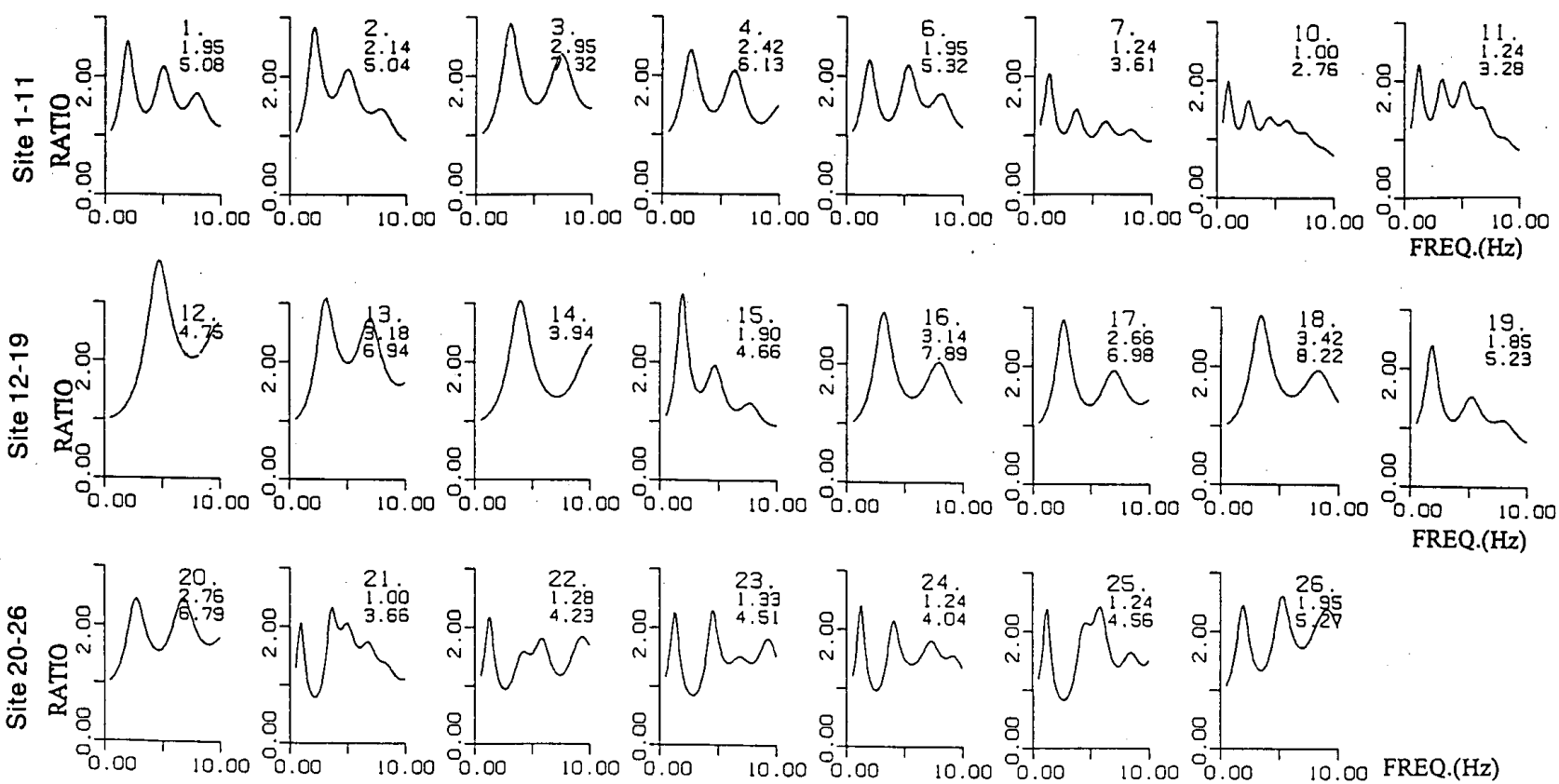

図 11 各地点の表層地盤の伝達特性
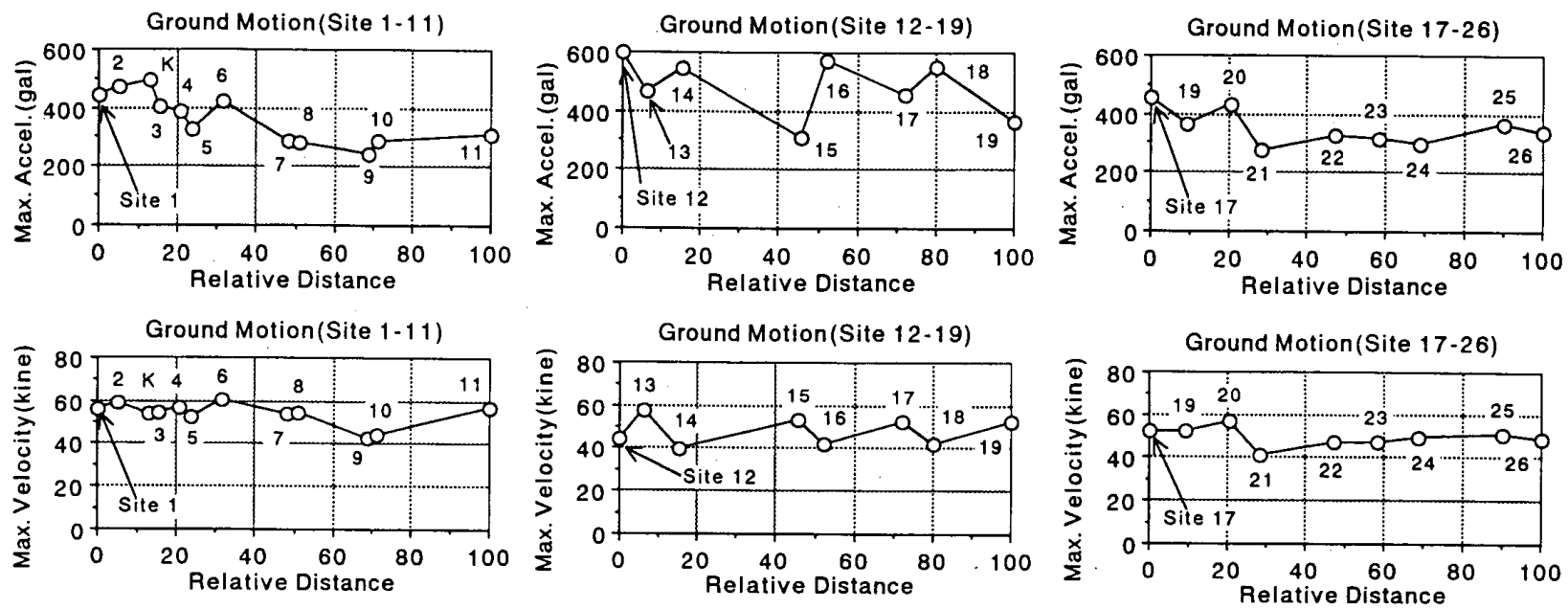

図 12 表層地震動の最大加速度・最大速度の分布 
一方、北海道の木造住宅は屋根が軽い、開口部がさい、 断熱材を壁内に配置するため壁が 2 重構造となり強度も 增している、などの理由よりせん断強度は本州などの住 家よりは高くなっていると考えられる。北海道の家屋の C y 分布については未だ明らかにはなっていないので直 接対応付けることはできないが、ここではせん断強度が 高くなった場合に地震応答・被害がどのように変化する かを調べるため、C $y=0.4$ の場合も併せ考慮した。

\section{(1) 構造被害の地域分布の推定}

図 13 には各建物の最上階の層間変形 ( R C 造の場合 は層間変形角）を図 12 と同様に示した。木造住宅につ いては、 $C y$ が 0.2 の場合は橋南(南)から橋北にかけて

\section{$(1 \sim 6)$ 、春採(北、南) (12１7)、橋南(北) (}

18，19）の地点で非常に大きな応答を示している。首 間変形 $5 \mathrm{c} \mathrm{m}$ 程度で半壊、 $10 \mathrm{~cm}$ 程度で全壊という従 来の経験的な被害評価尺度を当てはめてみると、これら の地区では半壊程度の被害は発生することとなる。しか し、Cy が 0.4 の場合は全体的に応答は小さくなり、ほ とんどの地区で半壊以下の評価となる。しかし、この場 合でも、橋南(北、南)や春採(北、南)では他地区に比へる 之相対的には応答は大きくなっており、これらの地区よ り被害が発生し始める可能性が示されている。一方、鉄

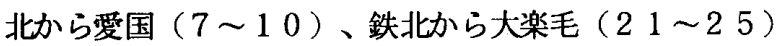
にかけては応答量は非常に小さくなっている。ただし、 大楽毛西（2 6) や湿原の近傍（1 1 1 ）ではやや大きな 応答を示している。建物の新旧で比較すると、ほとんど の地点で旧基準による建物は新基準のものに比べて 2 $3 \mathrm{c} \mathrm{m}$ 程度大きな応答を示している。
2 章で述べた実際の構造被害の対象はほとんどが木造 住家であったので、この被害の傾向（図3〜図6) と上 記の推定結果を比較する。釧路市域における木造住家の 耐力分布、構造形式、年代分布などを厳密に評価するに は、現状ではデータ不足なので、ここでは上記パラメー 夕（Cy、建物の新旧）のもとでの相対的な被害の変動 に着目して比較を行なう。旧釧路川より東の洪皘台地上 では、実際の被害は弥生・宮本町（橋南南）、緑ヶ岡東 部・材木町（橋南北）、武佐西部（春採北）などで大き かった。推定でもこれらの地点では、上に記したとうり、 相対的に大きな応答量を示しており、実際の被害の傾向 と一致している。しかし、推定では橋南(北、南)、春採 (北、南)でほぼ同程度の値を示しているのに対し、実際 には春採（北：武佐）、橋南（北：緑ヶ岡）で相対的に 大きな被害を生じている。2 章で記したように、この地 域では地盤の破壊による被害が多く発生したため、この ような差を生じたものと考えらる。このような地域では 振動による被害だけでなく、地盤変状による被害の推定 をも併せ行なうべきであろう。

一方、旧釧路川以西の沖積地では実際の被害は洪積台 地上の被害よりかなり小さかったが、推定でも同様の傾 向を示した。また、旧釧路川に近い橋北 $(3 \sim 6) \cdot$ ・鉄

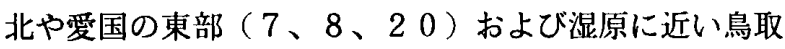
(北)（（1）では、釧路川に近い地区（9、1 0 ）より やや大きな被害を生じているが、この傾向は推定でも良 く表現されている。このように、沖積地では、表層地盤 の増幅特性を考慮した地震応答推定法による結果は、実 際の被害分布傾向を良く表現しているものと考えられる。
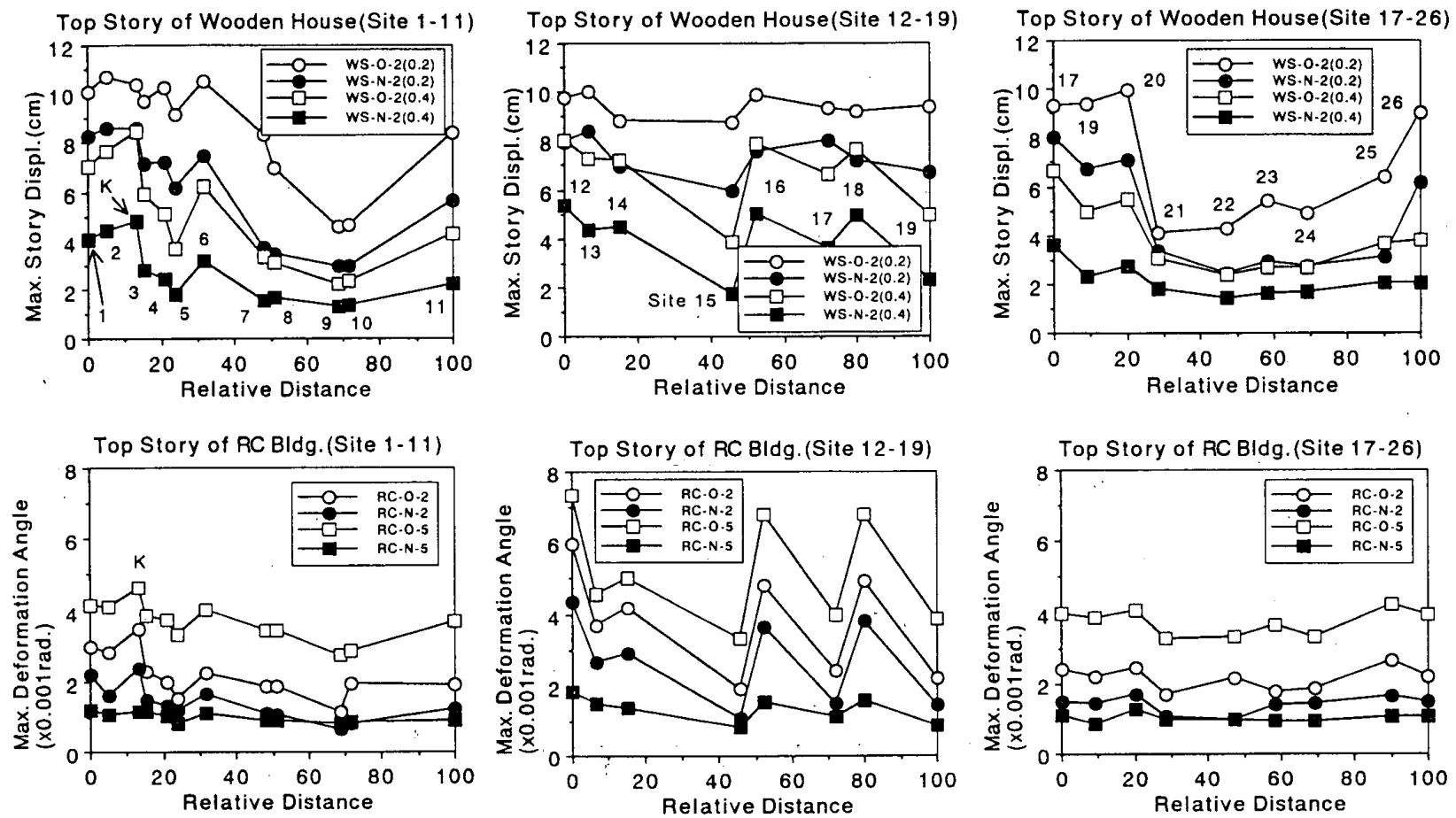

図 13 各地点での構造物の最大応答変位 (変形角) の推定 
$\mathrm{R} C$ 造に関しては、旧基準によって設計された構造物 は洪皘台地上の一部地区（春採(北)、橋南(北)) でやや大 きな応答を示している。また、気象台近傍（K）や春採 (南)でも首間変形の制限值 $(0.005 \mathrm{rad})$ に近い応答を 示した。しかし、その他の地点では応答は $0.005 \mathrm{rad}$ までは達しておらず、被害は軽微であったと推定される。 新基準による建物の応答量は非常に小さく、被害は発生 しない程度の応答量に留まっていた。また、全般的に 5 階建ての構造物の方が 2 階建てに比べて応答が大きくな っている。 R C 造の実際の被害分布については被害統計、 アンケート調查共にデー夕数が少なく、現状では推定結 果と比較することは難しい。今後のデータの蓄積を待っ て比較を行なっていきたい。

\section{（2）室内における散乱率の地域分布の推定}

図 14 には同様に各建物の室内における散乱率 $(R s)$ の分布を示した。ただし、ここでは対象とする部屋は各 解析ケースのすべてについて同じものとし、8 畳間に夕 ンスと厚みの薄い本棚がある場合を想定している。その ため、散乱率の絶対值については必ずしも意味のあるも のではなく、ここではその相対的な分布特性に注目する。 上段、下段はそれぞれ木造住家、R C 造建物の最上階で の散乱率を示している。また、図中の点線は 1 階フロア での散乱率（各建物共通）を表している。

散乱率の算定にはフロアの最大加速度・速度が関与す るが、1 階フロアでの散乱率を見ると、ほぼ表層地震動 の最大加速度・速度分布之相似の形状を持っているのが わかる。木造住家の最上階における散乱率の地域分布は 複雑な性状を示し、Cyの大小や建物の新旧による散乱 率の変化は一概には言えない。また、必ずしも 1 階フロ
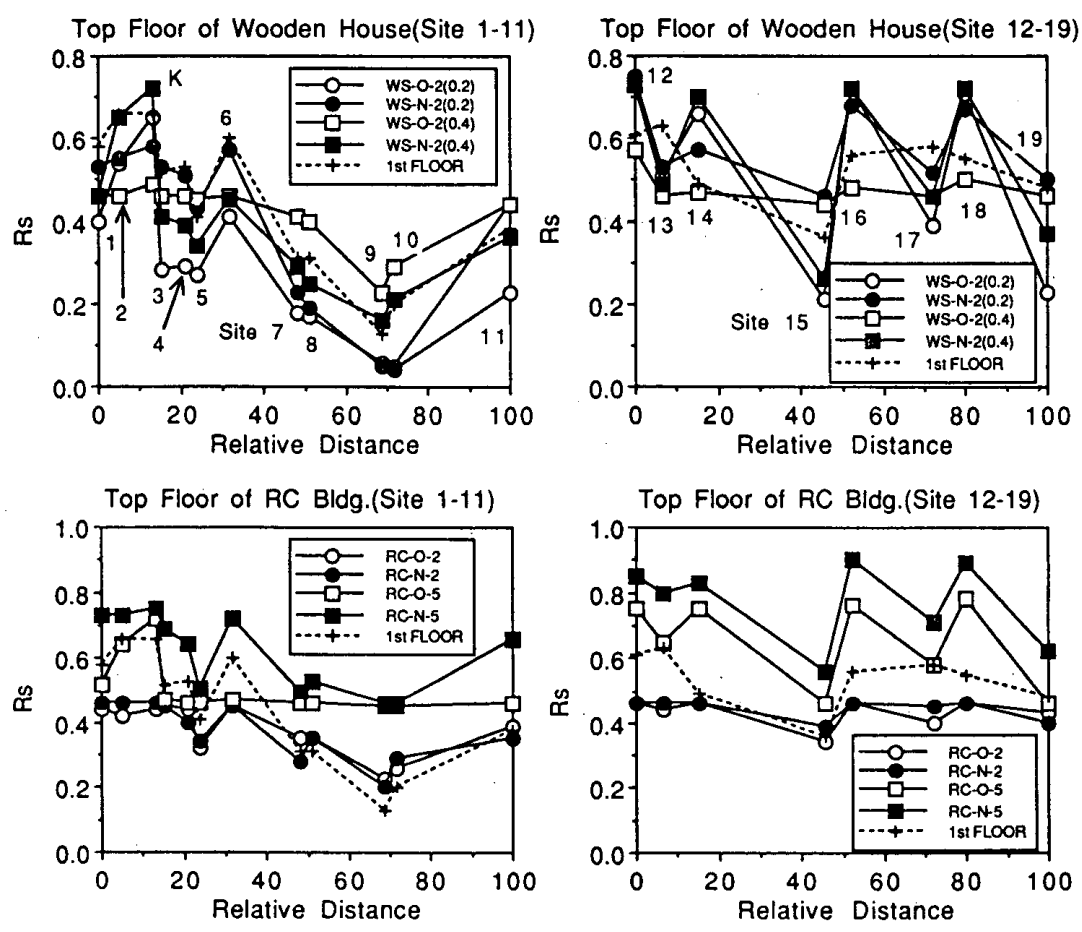

アの散乱率よりも大きいとはいえず、その関係は地域や 構造物の種類により変化する。しかしながら、構造被害 の小さかった沖積地（7１0、2 2 25）では $C y$ が 0.4 の場合の方が 0.2 の場合より、また旧基準によ る住家の方が新基準のものより散乱率は大きくなる傾向 を示している。一方、構造被害の大きかった橋南、春採 では新基準のものがやや大きくなる傾向を示した。この ように、散乱率は各フロアの応答加速度や応答速度に大 きく依存するため、構造物之入力（表層）地震動相互の 周波数特性の関保により、大きく変化するものと考元ら れる。

2 章で示した実際の散乱率（図 $8 、 9$ ）と推定結果を 比較すると、他地区に比へて散乱率が小さくなるのは、 推定では 1 階、最上階と屯鉄北、鳥取、大楽毛 $(7 \sim 1$

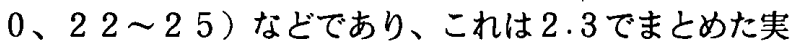
際の散乱率とも一致している。また、春採(西)や橋南(北、 南)（1、2、1 8 ）では散乱率は比較的大きかったが、 推定でもその傾向は示しており、散乱率のおおまかな分 布性状は追うことができているものと考えられる。しか し、春採(北、南)（1 2 17) では実際の被害はそれ ほどではなかったにもかかわらず、推定值は大きな值を 示したことなど、各地区における微妙な散乱状況の変化 については十分に表現し得ているとは言いがたい。推定 結果は構造物のパラメータ（耐力や建物の新旧など）に 大きく依存しているため、より詳細に解析結果と実際の 被害を比較していくためには、十分な被害デー夕を収集 し、これらを建物パラメー夕毎に整理して行く必要があ ろう。 R C 造建物については 5 階建ての最上階では、春 採や橋南地区で散乱は非常に大きくなる傾向を示してい

図 14 各地点での構造物の室内における散乱率Rsの推定
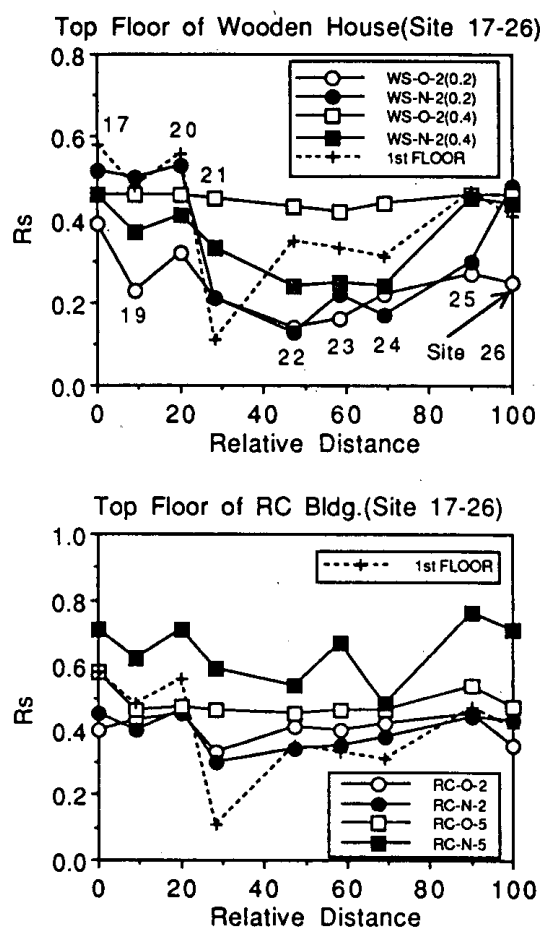
る。また、沖積地においても5階建ての最上階では地区 に係わらずかなりの散乱が発生することが読み取れる。

以上のように、実際の被害分布との比較により、本解 析によって構造被害・室内散乱の分布特性のおおよそを 定性的に追うことができたものと考えられる。特に沖積 層の卓越した地域ではかなりの精度で推定することが可 能であった。このことは、被害の分布特性は本解析で扱 っているように、各地点の表層地盤の特性（表層厚およ び表層の柔らかさなど、言い替えれば表層地盤の周波数 特性之増幅特性) および構造物のパラメー夕（耐力や建 物の新旧、階数など）を考慮することによって表現でき ることを示すものと考えられる。

\section{4.まとめ}

本研究では、建物の構造被害、室内被害の地域分布特 性を、1993年釧路沖地震による被害を対象にして、 被害調查およびアンケート調査によって得られた資料を もとにまとめた。さらに、これまでに開発してきた地震 被害推定手法を用いて構造的被害や居住空間における室 内被害を推定し、実際の被害分布との比較により推定法 の妥当性を検証すると共に、これらの結果を基に、建物 の構造被害・室内被害に影響をおよぼす要因（建物種別・ 耐力や表層地盤特性など）についての考察を行った。

本研究により、以下の諸点が明らかにされた。

1 ) 被害統計資料やアンケート調査結果を基に釧路市域 における建物の構造被害の分布特性を明らかにした。構 造被害は旧釧路川以東の台地上の地区で集中して発生し、 緑ヶ岡 6 丁目では $24 \%$ に達した。一方、旧釧路川以西 の沖積地や湿原付近の埋立地では被害率はあまり高くな かったが、被害率は旧釧路川から西方および北方へ行く につれ小さくなり、沖積首の厚さが薄いほど被害が大き くなる傾向を示した。

2 ）アンケート調查の結果に基づき家具の転倒や室内散 乱などの室内被害の分布を明らかにした。その結果、地 区によって建物の構造被害に比べて家具の転倒や室内の 散乱等が激しく発生していることが明らかとなった。こ れらの室内被害は、家具の転倒が顕著な地区や室内の散 乱が顕著な地区が存在するなど、非常に複雑な被害分布 性状を示している。

3)これまでに開発してきた推定手法によって構造的な 被害や室内の被害の分布の推定を行った。その結果、構 造的な被害および室内散乱などの被害の分布傾向を概略 追うことができた。これは、被害の分布特性は各地点の 表層地盤の特性を考虑することによってほぼ表現できる ことを示すものである。しかし、構造物の被害、特に室 内散乱については構造物の特性が大きく影響しているこ とが明らかであり、これらについても十分に考虑してい
く必要がある。また、洪積台地上での地域では地盤変状 による被害が卓越していることが明らかであり、地盤変 状に起因する建物被害についてはその被害メカニズムに 応じた推定手法を適用していく必要があろう。

本手法により、地盤条件および構造物の条件が得られ れば、物理的なモデルに基づいて構造物の応答さらには 構造被害や室内被害の推定が可能となろう。しかしなが ら、構造物への入力地震動の評価には多くの不完全な点 があり、またアンケート調査の結果にも不十分な点（母 数の絶対的な不足、回答の不確実性など）が存在するた め、現状では定量的な評価は難しいと考えられる。今後 はより多くの被害データの集積を図るとともに、より詳 細な検討を加え、本推定手法の精度向上を図っていく必 要があるものと考えられる。さらには、本手法による結 果をもとに、建物室内における 2 次被害の発生とその波 及、生活支障や経済的困穿を推定する手法についても構 筑していく予定である。

謝辞

アンケート調查の実施には北海道建築士会釧路支部お よび同十勝支部の事務局に大変お世話になった。また、 アンケートの回答には多くの会員の皆様のこ協力を頂い た。この場をかりて深甚なる感謝の意を表します。

参考文献

1) 北原昭男、藤原俤三 : 居住空間の構造的・機能的な地震被害の推定、京 都大学防災研年報、第35号B-1、pp.35 50、1992.4

2) 藤原涕三、岩井 哲、北原昭男 : 1993 年釧路沖地祳被害調查報告 （その 1 建築構造物の被害概況）、および（その2 建築物および室内の 地层被害の分布特性)、日本建築学会近楼支部研究報告集、第33号構造系、 pp.341 348、1993.6

3) 村上ひとみ、坂井忍、村上公一、高井伸婎：1993 年釧路沖地展の人 間行動調查一負倡者の発生亡病院の対応一、日本建策学会北海道支部研究報 告集、第66号、pp.17 20、1993.3

4 ）北原昭男、藤原悌三 : 都市における建策構造物の地祳被害推定に関する 基礎的研究（その1 木造構造物の地震応答推定）、京都大学防災研年埌、 第31号B-1、pp.105 126、1988.4

5) 北原昭男、藤原涕三 : 都市における建築構造物の地祳被害推定に関する 基碳的研究（その 2$)$ - 低層鉄筋コンクリート構造物の地酸応答推定一、京 都大学防災研年埌、第32号B-1、pp.149-163、1989.4

6 ）北原昭男、藤原涕三：建筑搆造物群の震害予測に関する研究、京都大学 防災研究所都市耐震センター研究報告、第 5 号、pp.11-39、1991.4

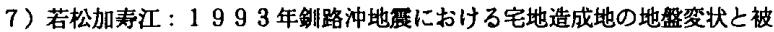

害、第 22 回地祳工学研究発表会講演概要集、pp.403-406、1993.7

8) 鹿島俊英、北川良和：平成 5 年（1993 年）釗路沖地祳強䟴観測速埌、 建設省建築研究所、1993.2

9）川瀬 博: 1993 年釗路沖地震で釧路気象台の強展地動は何故大きか ったのか? - 表層地質効果 (E S G) 仮説の提案一、日本建築学会大会学術 犝演梗概集、構造 I 、pp.15-16、1993.9

10）北海道建榮士会釧路支部：釧路市の地盤、 1982

11）鏡味洋史、後藤典俊、太田 㭲：各種土質指標を含む $S$ 波速度推定式の 系統的構成、日本建築学会大会学術講演梗概集、pp.509-510、1976.10 12）大崎順彦、原 昭夫; 清田芳治 : 地盤振動解析のための土の動力学モテ ルの提案と解析例、第 5 回日本地督工学シンポジウム、pp.697-704、1978 13）日本建築学会 : 非構造部材の酎縟設計指針 - 同解説および耐祳設計・施 工要領, pp.327-338、1985.11

14）松岡昌志、翠川三郎：1993 年釧路沖地䟴における釧路市内の地震動 強さ（その2 常時微動特性について）、日本建勧学会大会学術䡛演梗概集、 構造 I、pp.3-4、1993.9

(1993 年 9 月 8 日原稿受理, 1994 年 1 月 25 日採用決定) 